
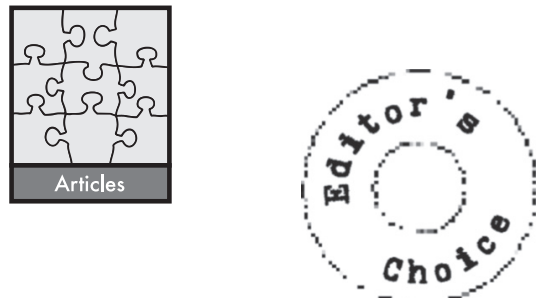

Journal of Avian Biology 45: 3-14, 2014

doi: 10.1111/j.1600-048X.2013.00177.x

(C) 2013 The Authors. Journal of Avian Biology (C) 2013 Nordic Society Oikos Subject Editor: Ronald Ydenberg. Accepted 3 September 2013

\title{
Common montane birds are declining in northern Europe
}

\author{
Aleksi Lehikoinen, Martin Green, Magne Husby, John Atle Kålås and Åke Lindström \\ A. Lehikoinen (aleksi.lehikoinen@helsinki.fi), Finnish Museum of Natural History, FI-00014 Univ. of Helsinki, Finland. - M. Green and \\ A. Lindström, Dept of Biology, Biodiversity Unit, Lund Univ., Ecology Building, SE-223 62 Lund, Sweden. - M. Husby, Nord-Trøndelag Univ. \\ College, Røstad, NO-7600 Levanger, Norway. - J. A. Kålås, Norwegian Inst. for Nature Research, PO Box 5685 Sluppen, NO-7485 Trondheim, \\ Norway.
}

\begin{abstract}
Large-scale multi-species data on population changes of alpine or arctic species are largely lacking. At the same time, climate change has been argued to cause poleward and uphill range shifts and the concomitant predicted loss of habitat may have drastic effects on alpine and arctic species. Here we present a multi-national bird indicator for the Fennoscandian mountain range in northern Europe (Finland, Sweden and Norway), based on 14 common species of montane tundra and subalpine birch forest. The data were collected at 262 alpine survey plots, mainly as a part of geographically representative national breeding bird monitoring schemes. The area sampled covers around 1/4 million $\mathrm{km}^{2}$, spanning 10 degrees of latitude and $1600 \mathrm{~km}$ in a northeast-southwest direction. During 2002-2012, nine of the 14 bird species declined significantly in numbers, in parallel to higher summer temperatures and precipitation during this period compared to the preceding $40 \mathrm{yr}$. The population trends were largely parallel in the three countries and similar among montane tundra and subalpine birch forest species. Long-distance migrants declined less on average than residents and short-distance migrants. Some potential causes of the current decline of alpine birds are discussed, but since montane bird population sizes may show strong natural annual variation due to several factors, longer time series are needed to verify the observed population trends. The present Fennoscandian monitoring systems, which from 2010 onwards include more than 400 montane survey plots, have the capacity to deliver a robust bird indicator in the climate-sensitive mountainous regions of northernmost Europe for conservation purposes.
\end{abstract}

Alpine species have in general received relatively little attention (Chamberlain et al. 2012), not least compared to common farmland (Matson et al. 1997, Benton et al. 2003, Gregory et al. 2005) and forest species (Hanski 2005, Gregory et al. 2007). This is despite the fact that alpine species and habitats are expected to change particularly rapidly during this century due to climate change (Huntley et al. 2007, Gonzalez et al. 2010), leading to an increased risk of extinction (Sekercioglu et al. 2008). Recent studies have documented poleward and uphill range shifts, providing strong evidence that living organisms respond to current climate change (Thomas and Lennon 1999, Parmesan 2006, Brommer and Møller 2010, Thomas 2010). Most studies have only documented shifts at the edge of the distribution, whereas changes in the centre of gravity of the species' abundance are rarely reported (Jiguet et al. 2010, Lindström et al. 2013). Whereas several studies have shown rapid range shifts in alpine plants and invertebrates (Grabherr et al. 1994, Parmesan 1996, Pauli et al. 1996, Luckman and Kavanagh 2000, Wilson et al. 2005, Kelly and Goulden 2008, Chen et al. 2011, Feeley et al. 2011), studies of alpine vertebrates are to our knowledge few. Since the first climate-driven extinctions in alpine areas have already been documented among amphibians (Pounds et al. 2006), there is an urgent need for improved knowledge about the conservation status of alpine vertebrates in general.

In Costa Rica, Peru and the US Sierra Nevada mountains, several bird species have shifted their distribution uphill (Pounds et al. 1999, Forero-Medina et al. 2011, Tingley et al. 2012). In the Swiss Alps, around 35\% of the bird species showed significant upslope expansion during 1999-2007 (Maggini et al. 2011), but in the Italian Alps, such a change was not detected despite a temperature increase of one degree during the 11-yr study period (Popy et al. 2010). There was no change in elevation boundaries in New York state birds between the 1980s and 2000s, despite the fact that birds were shifting their distribution polewards in general (Zuckerberg et al. 2009). The general lack of large-scale data on abundance changes of alpine birds partly stem from the logistic difficulties of monitoring birds in alpine regions. In their recent paper on the research status of alpine birds, Chamberlain et al. (2012) called for 'long-term monitoring programmes across a relatively broad area (a minimum of an entire mountain range) that could act as a baseline to monitor altitudinal shifts in bird communities in response to climate change, and environmental change more broadly'. 


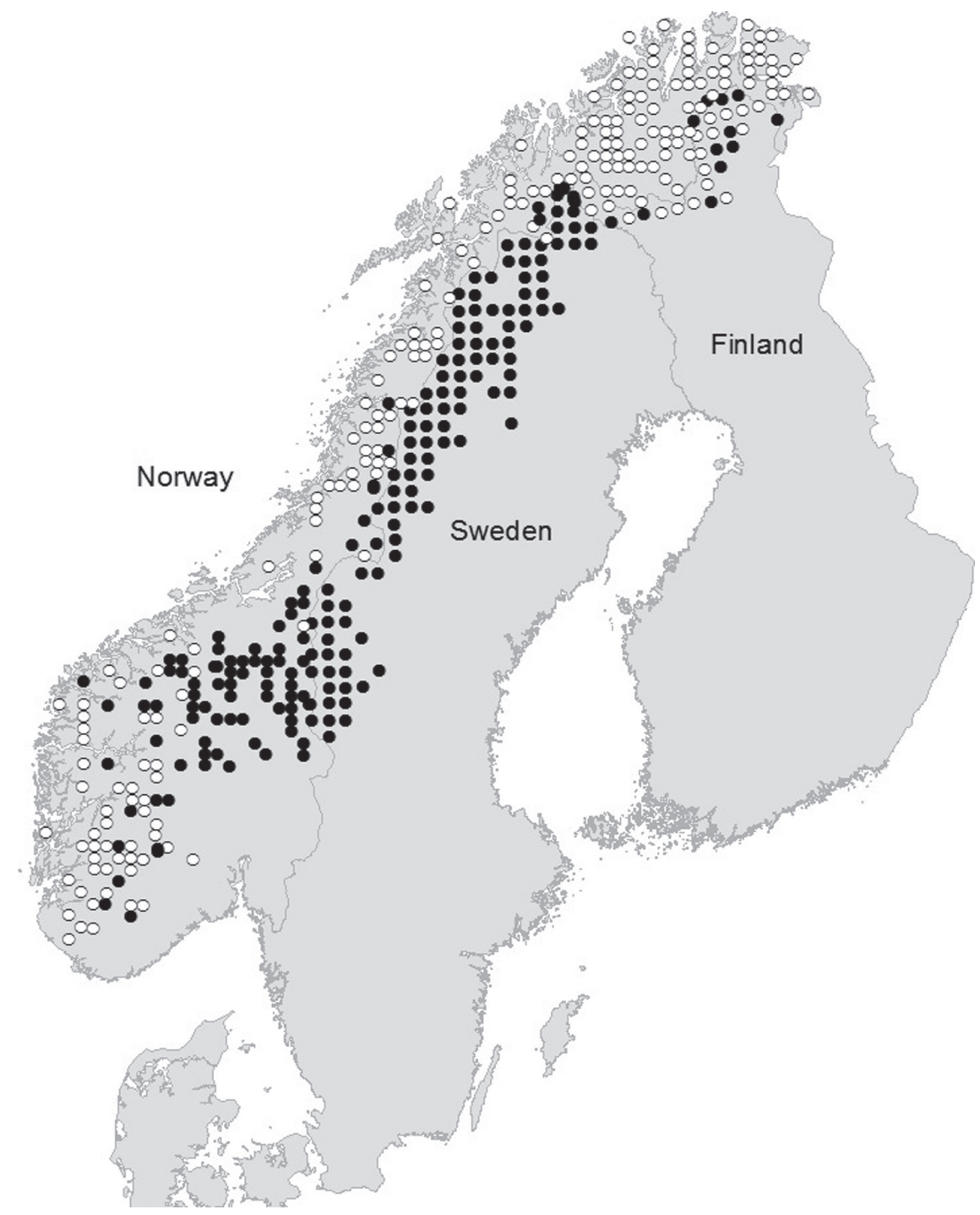

Figure 1. Map showing the 420 bird monitoring sites in the Fennoscandian mountain range. Black dots are sites with data for at least two years and therefore included in the present study $(n=262)$. White dots indicate newly established monitoring sites that have not yet been surveyed twice. Since the routes have been selected based on their dominating habitat, and there are routes systematically covering the total area of all three countries (not shown), the black and white dots give a representative picture of the extent of tundra and subalpine birch forest in Norway, Sweden and Finland.

The Fennoscandian mountain range spans through the whole of Norway, central and northern Sweden, and northernmost Finland (Fig. 1), with some peaks reaching $2000-2500 \mathrm{~m}$. Notwithstanding the almost bird-free areas of bare rock and glaciers at the very highest altitudes, the mountain range is dominated by two very conspicuous habitats: mountain tundra (hereafter 'tundra') and subalpine birch forest (hereafter 'birch forest'). Unlike in other parts of the world, birch forest forms the tree-line in the Fennoscandian mountains.

Given that global warming is predicted to continue, the extent, altitudinal position and habitat quality of both tundra and birch forest will most likely continue to change. In the southern part of the Fennoscandian mountain range, the treeline has shifted upwards with about $25-90 \mathrm{~m}$ in the last century, although with large local variation (Kullman and Öberg 2009). The upward shift of pine Pinus sylvestris and other tree species will probably continue, and may affect the area presently dominated by birch forest. If so, it may decrease the overall area of tundra and birch forest, but there are many uncertainties involved (Kullman and Öberg 2009).

Both the tundra and the birch forest have rather distinct bird faunas, not least in relation to each other. Many species are found mainly or only in one of these habitats. Given the ongoing climatic change it has been postulated that the birds of tundra should decline in numbers (Lindström and Agrell 1999, Huntley et al. 2007, Virkkala et al. 2008), but the extent of this decline is hard to predict because of the uncertainties outlined above. It is even less obvious how the birds of the birch forest will be affected, since changes in quantity and quality of the forest that may take place are less predictable. Nevertheless, as northern birds are predicted to experience loss of their breeding range due to climate 
change (Virkkala et al. 2008), we would expect to observe more negative than positive population trends among northern montane birds.

We here present population trends for 14 common bird species inhabiting tundra and birch forest, combining breeding bird survey data from Finland, Sweden and Norway for the period 2002-2012. The species trends are combined into a bird indicator (a multi-species trend; Gregory et al. 2005), which supposedly represents the status of the bird life in general in the Fennoscandian mountain range. In addition, we have investigated if the population development differs between the two main habitat types: mountainous tundra and subalpine birch forest. Furthermore, in order to evaluate the hypotheses for on-going changes in Fennoscandian montane birds, we assessed if changes in migration behaviour could explain the population trends, since long-distance migrants have on average done poorly in Europe in the last decades (Böhning-Gaese and Bauer 1996, Sanderson et al. 2006, Gregory et al. 2007, Brommer 2008, Ottvall et al. 2009).

\section{Material and methods}

Our study period covers the years 2002-2012, for which period there are relevant data from all three countries. The survey routes cover the full extent of the Fennoscandian mountain range, an area covering about $1 / 4$ million $\mathrm{km}^{2}$, with about $1600 \mathrm{~km}$ between the southwesternmost and northeasternmost routes (Fig. 1).

The tundra habitat of the montane areas occurs at an altitude of about $1300 \mathrm{~m}$ in the south and at sea level in the far north. It is dominated by low vegetation such as various grasses (Gramineae), dwarf birch Betula nana and low willows Salix sp. Towards lower altitudes the tundra is gradually replaced by subalpine birch forest Betula pubescens ssp. czerepanovii. This normally very distinct vegetation zone, where single trees are seldom taller than $10 \mathrm{~m}$, covers an elevation range of about $50-300 \mathrm{~m}$. At still lower altitudes the birch forest is gradually replaced by either spruce Picea or pine Pinus forest of the taiga zone (Kullman and Öberg 2009).

Given the distinct habitats and their distinct bird faunas (Väisänen et al. 1998, Husby and Kålås 2011, Ottosson et al. 2012, Thompson et al. 2012), it was relatively easy to designate both routes and species to represent alpine birds in Fennoscandia. All survey routes are situated in tundra and/or birch forest.

\section{Monitoring schemes and route selection}

All data from Sweden originate from one single monitoring scheme for the entire period. The data from Norway and Finland originate from different types of counts in 2002-2005, but from 2006 onwards the main bulk of data come from almost identical sampling schemes in the three countries. The annual numbers of survey sites in each country are shown in Table 1.

\section{Finland}

The Finnish data originate from two different schemes. In the period 2002-2012, six line transects at various locations
Table 1. Annual number of counted routes in Finnish (altogether 23 routes), Swedish (104) and Norwegian (135) mountain area that were used in the analyses.

\begin{tabular}{lccc}
\hline Year & Finland & Sweden & Norway \\
\hline 2002 & 4 & 36 & 10 \\
2003 & 6 & 44 & 10 \\
2004 & 4 & 31 & 9 \\
2005 & 4 & 36 & 9 \\
2006 & 8 & 39 & 26 \\
2007 & 17 & 58 & 58 \\
2008 & 5 & 78 & 71 \\
2009 & 5 & 69 & 75 \\
2010 & 6 & 58 & 68 \\
2011 & 13 & 68 & 98 \\
2012 & 16 & 68 & 106 \\
\hline
\end{tabular}

in mountains have been surveyed as a part of the national bird monitoring scheme (4-6 sites surveyed annually). In addition, in 2006, a countrywide system of 560 randomly chosen fixed line transect routes was established (Väisänen 2006). A route is $6 \mathrm{~km}$ long, shaped like a $1 \times 2 \mathrm{~km}$ rectangle. Surveys have been conducted between 9 June-9 July during early morning, normally between 4:00 and 9:00 am local time, in fair weather with weak or no wind. The surveyor should walk at a speed of 45-60 min km-1 depending on the density of birds (Koskimies and Väisänen 1991, Lehikoinen 2013). Based on habitat descriptions, 33 of these fixed line transects were considered to be in the montane areas. All were surveyed in 2006-2012, and 17 of them were surveyed at least two years during this period (1-13 sites surveyed annually). From this project, only those 17 transects were included in the trend calculations and used in the analyses together with the initial six line transects (Fig. 1).

\section{Sweden}

The Swedish data stem from the so called fixed routes (Lindström et al. 2013). In total 716 routes are distributed systematically over Sweden, with $25 \mathrm{~km}$ between routes in both north-south and west-east directions. Each route is an $8 \mathrm{~km}$ line transect, shaped like a $2 \times 2 \mathrm{~km}$ square. The survey starts in the southwest corner of the route at 4:00 am local summer time and the surveyor should walk at a speed not exceeding $30-40 \mathrm{~min} \mathrm{~km}^{-1}$. However, particularly in mountainous regions, speed may be lower than this due to difficult terrain. Accordingly, the surveyor returns to the starting point 5-7 h later. All individual birds heard and seen along the route are counted. The surveyor is allowed to deviate up to $200 \mathrm{~m}$ from the planned route. When larger detours are needed, due to water bodies, steep slopes or glaciers, the counting stops and is resumed when the surveyor can get within $200 \mathrm{~m}$ of the line again.

The Swedish fixed routes programme has been running since 1996. The aim is to survey each route annually, but so far the highest annual count has been 584. A total of 104 routes were considered montane routes (Fig. 1). Given the large difference in altitude within many of the routes, some Swedish and Norwegian routes also contain stretches of spruce forest (in deep mountain valleys). Several routes are many tens of $\mathrm{km}$ from the nearest roads and have to be reached by helicopter. All 104 alpine routes have been surveyed at least twice, and on average 5.6 times in the 
$11 \mathrm{yr}$ (range 2-10). The timing of the surveys varied between 23 May and 19 July, with 90\% carried out between 8 June and 7 July.

\section{Norway}

In Norway the collection of data in a randomized network of routes has been developed since 2005. This network includes approximately 500 sites randomly selected among 1030 sites distributed systematically over Norway in an $18 \mathrm{~km}$ northsouth and $18 \mathrm{~km}$ east-west network, and 267 of these include montane or sub-alpine habitats. Counting of birds is done by point counts at 20 points which are situated $300 \mathrm{~m}$ apart and form a $1.5 \times 1.5 \mathrm{~km}$ square. In addition, all observations of non-passerine birds (and a few pre-selected passerine species) observed while moving between the counting points are registered. The number of observations for each sampling route is the sum of observed pair equivalents of birds at the counting points $(5$ min counting period at each point) and while moving between counting points (Kålås and Husby 2002). For some of the routes, the number of counting points can be less than 20 (but always $>12$ ) because of reduced availability (lakes, cliffs, rivers, etc.). Generally counts are done between 23 May and 7 July, in suitable weather conditions and between 4:00-10:00 am local time. Each route has its own standard procedure (order of counting points, date-interval suitable for counting, starting time, etc.), and sampling sites are identified by the use of GPS. In total 125 of these routes are included in the trend analyses in this study as they have been counted at least twice in the period 2006-2012. The breeding bird survey in the northeasternmost part of Norway has just started and is only partly included in this paper (Fig. 1).

In addition we also included data from 10 survey routes from five montane areas in Norway, surveyed annually during the period 2002-2009 (two routes in each area, one in birch forest and the other in tundra). These are point counts done at 20 points situated $250-300 \mathrm{~m}$ apart along routes located to cover the relevant habitat types.

In Finland and Norway, the survey unit is a pair of birds and thus the birds observed are translated into pairs (observations of singing male, male and female together, or parent with offspring is transformed into one pair; Koskimies and Väisänen 1991). In general, most of the observations concern singing males. In Sweden, the survey unit is the number of adult individuals (males as well as females, but not young of the year). Accordingly, Swedish bird numbers are somewhat too high in direct comparison to Finnish and Norwegian numbers. We tested the potential importance of this by dividing Swedish numbers by 2.0 (assuming each observation concerned a pair of birds), 1.5 (assuming every second observation has concerned a pair of birds) and 1.0 (no transformation). Since the combined population trends were more or less uniform (Appendix 1), we decided to use the non-transformed Swedish numbers in the analyses.

In all three countries, the montane areas are characterized by low human density, including ornithologists. In addition, the terrain is often difficult and many study sites are situated far from roads. Because of this, and in contrast to the volunteer-based monitoring in the southern or loweraltitude parts of Finland, Sweden and Norway, most surveyors of montane routes in the three countries are often paid.

\section{Study species selection}

Because we selected routes based on habitat, the species selection was fairly straightforward. We simply included the species most commonly recorded on the selected routes, typical for either the tundra or the birch forest habitat (Väisänen et al. 1998). Given that many survey routes cover both tundra and birch forest and the surveyors have not assigned the exact position of each bird, it was impossible to assign each individual to a specific habitat. On the other hand, there is little overlap in species composition of the two habitats, which makes it easy to assign a given species to either of the habitats. Seven species are included for each habitat (tundra and birch forest). Altogether these 14 species made up $81 \%, 81 \%$ and $66 \%$ of all bird observations in the survey data of the mountainous regions in Finland, Sweden and Norway, respectively.

In the tundra group, four species exclusively occur in this habitat in Fennoscandia (Table 2). The three other species have their population stronghold in alpine areas,

Table 2. Common mountain bird species of Fennoscandia used in the analyses and their main breeding habitat (tundra or birch forest) and migration strategy $(R=$ resident, $S=$ short-distance migrant, $L=$ long-distance migrant, Cramp et al. 1977-1994) and average migration distance in kilometres (Methods). Species in bold are found exclusively in this habitat in Fennoscandia. Species marked with asterisk (*) have too few data in one of the countries.

\begin{tabular}{|c|c|c|c|c|}
\hline Species & Scientific name & Habitat & Migration & Migr. distance \\
\hline Willow ptarmigan & Lagopus lagopus & birch forest & $R$ & 0 \\
\hline Rock ptarmigan* & L. muta & tundra & $\mathrm{R}$ & 0 \\
\hline Golden plover & Pluvialis apricaria & tundra & S & 2400 \\
\hline Long-tailed skua* & Stercorarius longicaudus & tundra & $\mathrm{L}$ & 10000 \\
\hline Meadow pipit & Anthus pratensis & tundra & S & 3200 \\
\hline Bluethroat & Luscinia svecica & birch forest & $\mathrm{L}$ & 6500 \\
\hline Common redstart & Phoenicurus phoenicurus & birch forest & $\mathrm{L}$ & 7000 \\
\hline Common wheatear* & Oenanthe oenanthe & tundra & L & 7000 \\
\hline Redwing & Turdus iliacus & birch forest & S & 3000 \\
\hline Willow warbler & Phylloscopus trochilus & birch forest & $\mathrm{L}$ & 8500 \\
\hline Brambling & Fringilla montifringilla & birch forest & S & 2000 \\
\hline Common redpoll & Carduelis flammea & birch forest & S & 1400 \\
\hline Lapland bunting* & Calcarius lapponicus & tundra & $S$ & 2800 \\
\hline Snow bunting* & Plectrophenax nivalis & tundra & S & 2000 \\
\hline
\end{tabular}


but also occur in low-altitude open habitats elsewhere in Fennoscandia (Väisänen et al. 1998, Svensson 2006, Ottosson et al. 2012). Among the birch forest species, only the bluethroat Luscinia s. svecica is a subalpine birch forest specialist. However, among the remaining six species, three reach their highest densities in this habitat (Ottosson et al. 2012) and the others have prominent populations in the subalpine birch forest (Enemar et al. 2004).

To be able to evaluate hypotheses for on-going changes in Fennoscandian montane birds, species were classified either as long-distance migrants (spending the winter either in sub-Saharan Africa or in southern Asia), or shortdistance migrants (residents and species wintering in Europe, Cramp et al. 1977-1994).

\section{Weather data}

Weather data for all survey plots included in calculating the indicator were retrieved from each country's meteorological institute. Data from approximately 100 Finnish weather stations were interpolated to a $10 \times 10 \mathrm{~km}$ grid of virtual weather stations (Venäläinen et al. 2005). Correspondingly, data from all weather stations around Sweden (approximately 300 stations spread evenly over the country) were interpolated to a $4 \times 4 \mathrm{~km}$ grid of virtual weather stations, using geo-statistic interpolation (Johansson 2000). For the analyses, we selected the virtual site nearest each mountainous plot, resulting in 16 and 104 virtual weather sites for Finland and Sweden, respectively. From approximately 200 Norwegian weather stations measuring temperature and approximately 500 stations measuring precipitation, data were interpolated in a $1 \times 1 \mathrm{~km}$ grid providing a virtual weather site as close as possible to the middle of each survey route. For each site, we calculated the average of the May to August mean temperature and precipitation.

\section{Analyses}

We used log-linear regression (program Trends and Indices for Monitoring data, TRIM, Pannekoek and van Strien 2004, <www.ebcc.info/trim.html >) to estimate annual bird abundances. We first combined all survey locations from all three countries in species-specific analyses. For species which had annual data from all three countries, we used the country as a covariate, otherwise the abundance of species was analysed without a regional covariate (Table 2). As the number of study sites in each country was proportional to the amount of habitat in each area (Fig. 1), there was no major bias in the regional sampling. The only sub-regions having a poorer coverage were northeastern Finland and Norway (Fig. 1). In addition, we calculated country-specific trends for species which had at least four pairs observed annually (four individuals in the Swedish data). This allowed us to investigate the concordance of national species trends.

Combined species indices (used as the indicator) were calculated by taking the geometric mean of the speciesspecific yearly indices (TRIM) for the species involved. Standard errors for geometric means were computed from the indices and standard errors of individual species (Gregory et al. 2005). In addition, we compared the trends between the two species groups (tundra and birch forest) by doing an analysis of variance (ANOVA) test using the additive slope as provided by TRIM (Gregory et al. 2007). Furthermore, we tested if the species-specific population trends were related to the log-transformed migration distance $\left(\log _{10}(\right.$ distance +1$\left.)\right)$, using linear regression. The migration distances were calculated based on information of ringing recovery atlases and distribution maps (distance between northern Sweden and mean wintering region of the species; Cramp et al. 1977-1994, Fransson et al. 2008, Fransson and Hall-Karlsson 2008, Gilg et al. 2013; Table 2).

\section{Results}

By combining the 'Common breeding bird monitoring' programs from Finland, Sweden and Norway, we identified more than 400 survey plots suitable for monitoring breeding montane birds in the Fennoscandian mountain range (Fig. 1). We present data on population changes for the period 2002-2012 based on data from 262 of these plots. These data showed that nine species declined significantly, while none increased significantly during the period (Table 3). The montane bird indicator, the geometric mean of species-specific abundance indices for all 14 species, decreased by about $29 \%(21-36,95 \%$ CI) in 2002-2012 (Fig. 2a).

In Finland, three species out of nine declined significantly and one species showed a significant increase. In Sweden, eight species out of 13 declined significantly and none increased. In Norway, eight species out of ten showed a significant decline and none increased (Table 3). The long-term population trajectories of the species were very similar between the countries with respect to significant population trends, and the species-specific population trends were always in the same direction in all three countries (Table 3). The between-year variation in indices was also very similar in the three countries (Fig. 2b, 3). The detrended annual Finnish index for the nine species (the residuals from a linear regression of the index on year) correlated significantly positively with the corresponding indices from Sweden and Norway, respectively $\left(r_{s}=0.26, n=99, p=0.009\right.$, and $r_{s}=0.32$, $\mathrm{n}=99, \mathrm{p}=0.001$; Fig. 3a-b). However, the Swedish and Norwegian values showed the strongest intercorrelation (nine species, $r_{s}=0.50, n=99, p<0.001$; Fig. $3 c$ ).

The general decline of species in the multi-national data set concerned both tundra and birch forest species, with no significant difference between the groups (ANOVA, $F_{1,12}=1.35, p=0.27$, Fig. 4a). However, the indicator for long-distance migrants was less negative than that for shortdistance migrants and residents (ANOVA, $\mathrm{F}_{1,12}=5.28$, $p=0.04$, Fig. $4 b$ ). The species trends were also highly significantly correlated to average species-specific migration distance $\left(\mathrm{F}_{1,12}=22.7, \mathrm{n}=14, \mathrm{~b}=0.029 \pm 0.006, \mathrm{p}=0.0005\right)$. This pattern remained significant also after removing the two resident ptarmigan species from the analysis $\left(\mathrm{F}_{1,10}=7.31\right.$, $\mathrm{b}=0.076 \pm 0.028, \mathrm{p}=0.022$ ).

Summer temperatures (the average for May-August) within the Fennoscandian mountain range increased in 1961-2011 (Fig. 5a). Although temperatures actually decreased within the shorter period 2002-2011, that very 
Table 3. Mean annual additive growth rates (and their standard errors) of 14 common mountain bird species of Fennoscandia in the whole area and in each country during 2002-2012 calculated by the TRIM software. Species-specific annual sample sizes (n; Methods) in each country are also given. ' - ' means that there were too few data to calculate the trend for that country. Significantly decreasing or increasing population trends are in bold.

\begin{tabular}{|c|c|c|c|c|c|c|c|}
\hline Species & $\begin{array}{l}\text { Whole area } \\
\text { trend }\end{array}$ & $\begin{array}{l}\text { Finland } \\
\text { trend }\end{array}$ & $\mathrm{n}$ & $\begin{array}{l}\text { Sweden } \\
\text { trend }\end{array}$ & $\mathrm{n}$ & $\begin{array}{c}\text { Norway } \\
\text { trend }\end{array}$ & $\mathrm{n}$ \\
\hline Willow ptarmigan & $-0.149 \pm 0.032$ & $-0.066 \pm 0.036$ & $9(4-16)$ & $-0.132 \pm 0.017$ & $75(47-119)$ & $-0.168 \pm 0.047$ & $43(6-85)$ \\
\hline Rock ptarmigan & $-0.105 \pm 0.019$ & - & $3(0-9)$ & $-0.099 \pm 0.021$ & $35(18-51)$ & - & $20(3-63)$ \\
\hline Golden plover & $0.003 \pm 0.010$ & $0.019 \pm 0.032$ & $22(4-50)$ & $0.015 \pm 0.008$ & 449 (232-739) & $-0.011 \pm 0.014$ & $338(52-786)$ \\
\hline Long-tailed skua & $0.032 \pm 0.022$ & - & $3(0-15)$ & - & $69(2-120)$ & - & $8(0-16)$ \\
\hline Meadow pipit & $-0.032 \pm 0.008$ & $-0.034 \pm 0.017$ & $145(50-330)$ & $-0.031 \pm 0.008$ & $888(405-1303)$ & $\mathbf{- 0 . 0 3 3} \pm 0.012$ & $604(173-1243)$ \\
\hline Bluethroat & $-0.030 \pm 0.016$ & $0.007 \pm 0.021$ & $61(32-110)$ & $-0.010 \pm 0.014$ & $127(62-199)$ & $-0.089 \pm 0.031$ & $53(19-127)$ \\
\hline Common redstart & $0.012 \pm 0.013$ & $0.065 \pm 0.021$ & $40(14-104)$ & $0.015 \pm 0.013$ & 250 & $-0.008 \pm 0.022$ & $105(32-206)$ \\
\hline Common wheatear & $-0.020 \pm 0.014$ & - & $19(1-48)$ & $0.003 \pm 0.013$ & $176(81-307)$ & $-0.042 \pm 0.020$ & $126(32-283)$ \\
\hline Redwing & $-0.048 \pm 0.010$ & $-0.011 \pm 0.018$ & $53(24-166)$ & $-0.056 \pm 0.010$ & $332(202-427)$ & $-0.058 \pm 0.019$ & $186(23-340)$ \\
\hline Willow warbler & $-0.044 \pm 0.006$ & $-0.055 \pm 0.012$ & $423(184-1027)$ & $-0.054 \pm 0.007$ & 1765 (1419-2480) & $-0.030 \pm 0.009$ & $1149(382-1902$ \\
\hline Brambling & $-0.060 \pm 0.008$ & $-0.021 \pm 0.023$ & $231(60-536)$ & $-0.048 \pm 0.008$ & $1029(659-1483)$ & $-0.097 \pm 0.013$ & $333(117-585)$ \\
\hline Common redpoll & $-0.091 \pm 0.015$ & $-0.065 \pm 0.017$ & $158(47-352)$ & $-0.063 \pm 0.015$ & 452 (95-1094) & $-0.151 \pm 0.025$ & $113(34-210)$ \\
\hline Lapland bunting & $-0.050 \pm 0.014$ & - & $20(0-70)$ & $-0.058 \pm 0.015$ & $208(77-283)$ & - & $24(2-66)$ \\
\hline Snow bunting & $-0.034 \pm 0.018$ & - & $6(1-14)$ & $-0.034 \pm 0.022$ & 44 (17-88) & - & $8(0-25)$ \\
\hline
\end{tabular}

period was on average more than one degree warmer than the preceding period $1961-2001\left(8.3^{\circ} \mathrm{C} \pm 0.7(\mathrm{SD})\right.$ versus $7.2^{\circ} \mathrm{C} \pm 0.8(\mathrm{SD}), \mathrm{t}$-test $\left.\mathrm{t}_{49}=4.15, \mathrm{p}<0.001\right)$. Precipitation during the summer also increased in 1961-2011 (Fig. 5b). Annual variation was high, but on average 2002- 2011 tended to be wetter than the preceding $40-\mathrm{yr}$ period $(82.2 \mathrm{~mm} \pm 12.8(\mathrm{SD})$ versus $73.7 \mathrm{~mm} \pm 13.2(\mathrm{SD})$, t-test $\left.\mathrm{t}_{49}=1.83, \mathrm{p}=0.074\right)$.

\section{Discussion}

This work presents for the first time population trends for the common montane birds covering the whole Fennoscandian mountain range. Long-term species-specific population trends have previously been reported only from single sites within this mountain range (Väisänen et al. 1998, Enemar et al. 2004, Svensson 2006, Nyholm 2011, Byrkjedal and Kålås 2012). A majority of the species included in our study declined significantly in numbers during 2002-2012. As these declines were synchronous in all three countries and occurred both in tundra and birch forest, one may suspect that they were driven by the same large-scale phenomena. The results are in line with previous studies from the US Sierra Nevada mountains, where the overall species diversity has declined during the 20th century (Tingley and Beissinger 2013).
It is known from single study sites in the Fennoscandian mountains that some of the indicator species, and also other montane species, have faced previous decadal-long declines in the latter half of the 1900s, from which they recovered rather quickly (Enemar et al. 2004, Svensson 2006). However, to our knowledge, such a general and simultaneous decline among the most common species in the Fennoscandian mountains has not been observed before, and the pattern is both striking and worrying. Whereas a period of $11 \mathrm{yr}$ is too short to allow detailed analyses and interpretations of potential causes of annual population declines, we will nonetheless briefly discuss some potentially important factors for consideration in future analyses.

A well-established pattern in European common birds is the disproportionate decline of long-distance migrants (Böhning-Gaese and Bauer 1996, Sanderson et al. 2006, Gregory et al. 2007). In contrast, the population trends of the five long-distance migrants in our species pool were significantly less negative than those of short-distance migrants and residents. Therefore it seems unlikely that the overall population declines are caused by problems in the tropical wintering areas (Hewson and Noble 2009). Interestingly, the difference between the migratory groups is similar to that of European farmland species, which also show a more dramatic decline in short-distance than in long-distance
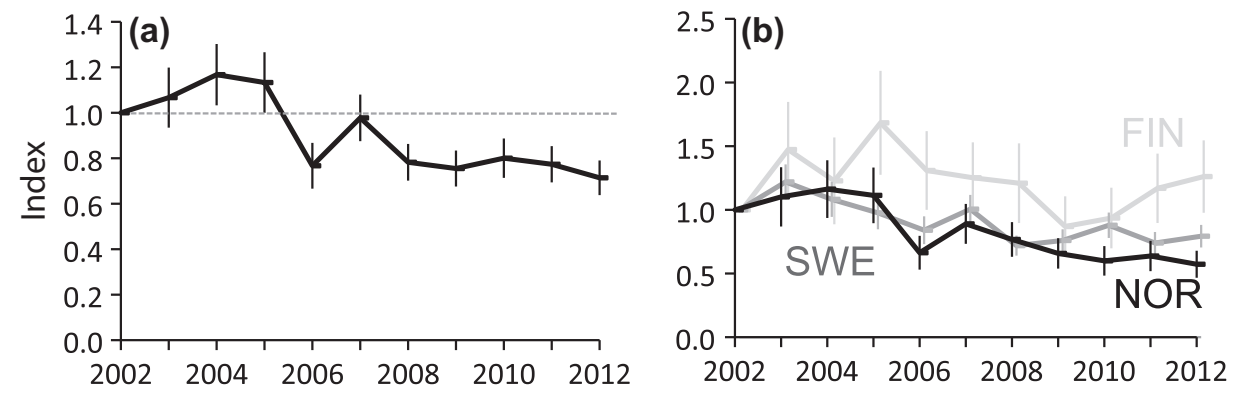

Figure 2. Geometric mean (bars indicating the $95 \% \mathrm{CI}$ ) of the abundance indices of 14 montane birds (a) using combined data from Finland, Sweden and Norway and (b) country-specific means of the same nine species (Finland = light grey, Sweden $=$ dark grey and Norway $=$ black $)($ Table 1$)$. 

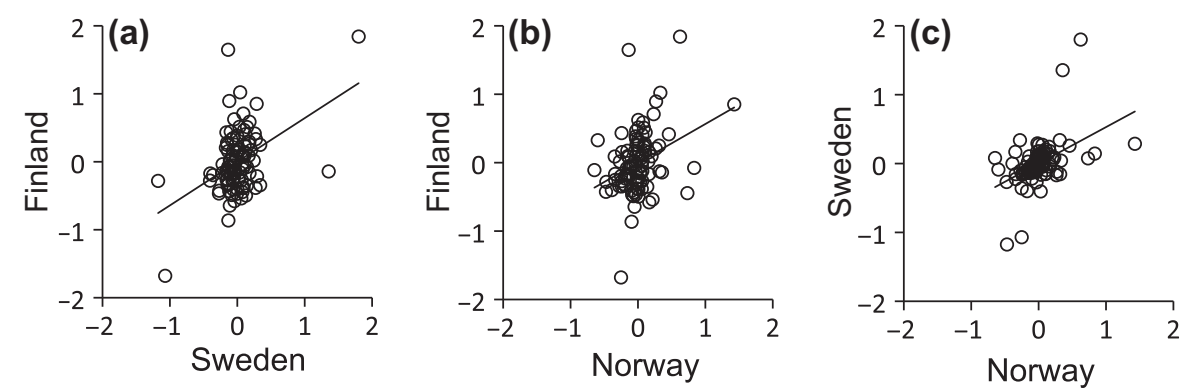

Figure 3. The relationship between the time-detrended abundance indices of nine species in (a) Finland and Sweden, (b) Finland and Norway, (c) Sweden and Norway (Table 1).

migrants in recent years (Voříšek et al. 2010). We also found that the species-specific population trends were negatively related to migration distance. Since migration distance is roughly proportional to the time that a species is spending on the breeding grounds, this indicates that species which are spending the least time in the breeding areas are doing relatively better.

Like in farmland birds (Gregory et al. 2005), the main reasons for the population declines may thus be found on the breeding grounds and potentially outside the main breeding season. Whatever the true driving forces are behind the observed pattern, the general decline is in line with predictions for northern montane populations, at least for the tundra-dwelling species. Due to climate change, the suitable climatic niches of montane species are expected to retract northwards and uphill until the end of the present century (Huntley et al. 2007, Tingley et al. 2009). Because population sizes and range sizes are typically strongly linked (Brommer 2008), this means that retracting populations are likely to decline. In addition, current breeding population trends have been shown to mirror forecasted changes in climatic suitability in Sweden (Jiguet et al. 2013), and, likewise, 91\% of the montane birds species tracked changes in their climatic niche in the Sierra Nevada mountains (Tingley et al. 2009).

Available data also show a change in regional weather conditions during the last decades. The average summer temperatures during 2002-2011 were about 1 degree higher than in the preceding $40 \mathrm{yr}$ and precipitation was also higher in the latter period. Both factors are known to affect the vegetation structure and distribution in the
Fennoscandian mountains (Kullman and Öberg 2009, Olofsson et al. 2009, Öberg and Kullman 2011). Increased rainfall may also hamper breeding success (Newton 1998), as the nesting sites of montane species are typically open and thus exposed to rain (Cramp et al. 1977-1994). It has been suggested that alpine and arctic birds will face increasing breeding challenges due to increased climate variability associated with climate change (Martin and Wiebe 2004). For instance, climate can shape the timing of breeding and nestsite selection of ptarmigans (Wiebe and Martin 1998, Wilson and Martin 2010), which can affect predation risk of both the nest and the incubating females (Wiebe and Martin 1998, Wilson et al. 2007). Furthermore, climate change may alter the fitness consequences of alternative life-history strategies within the alpine ecosystem, where individuals breeding at the highest elevations may have the lowest breeding success due to a shorter breeding season, but this may be compensated for by improved survival compared to individuals nesting at a lower altitude (Bears et al. 2008). On the other hand, the effect of climate on life-history characteristics has shown to be the opposite when comparing arctic and alpine regions. In ptarmigans, reproductive success increased and survival decreased from alpine regions to arctic areas in North America (Sandercock et al. 2005).

Changes in the forest composition are also possible drivers of population change. Pine has in recent times moved faster uphill than birch, and may hence replace some of the current birch belt (Kullman and Öberg 2009). However, predictions of future scenarios are hard to make since wind exposure, effects of snow, weather variability, geomorphological processes and herbivore-climate interactions most
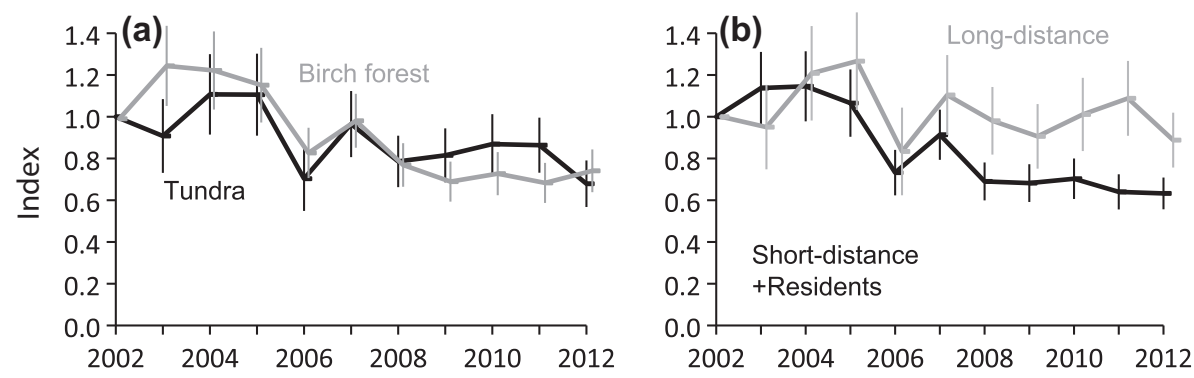

Figure 4. Geometric mean (bars indicating the 95\% CI) of the abundance indices of montane birds from Finland, Sweden and Norway using (a) combined indices for birch forest $(n=7$ species, grey symbols) and tundra habitat $(n=7$, black), and (b) combined indices for long-distance migrants $(\mathrm{LDM})(\mathrm{n}=5$, grey symbols) and the remaining species (short-distance migrants $(\mathrm{SDM})+$ residents) $(\mathrm{n}=9$, black $)$. 
(a)

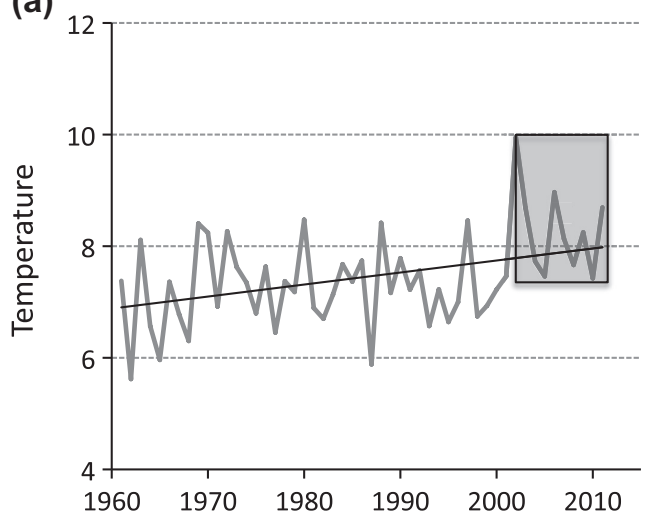

(b)

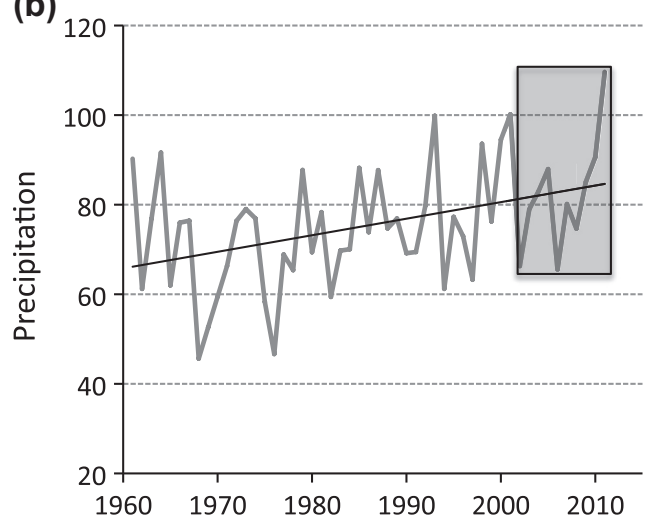

Figure 5. The average (a) temperature $\left({ }^{\circ} \mathrm{C}\right)$ and (b) precipitation $(\mathrm{mm})$ in May to August $1961-2011$ at the Fennoscandian survey plots (Fig. 1). The boxes denote the time period for which bird census data were available.

probably will affect the exact outcome. Due to the joint operation of all of these factors, some parts of the tundra are likely to remain treeless for a foreseeable future (Kullman and Öberg 2009, Olofsson et al. 2009, Öberg and Kullman 2011, van Bogaert et al. 2011).

Apart from changes in the distribution and area of whole vegetation zones, also their quality from the birds' point of view may change. For example, global warming has expanded the distribution of insect pests on birches, which can cause large-scale defoliations (Jepsen et al. 2008, 2011). This is not necessarily a drawback for the forest birds, since larval outbreaks form a crucial food source for some bird species (Lindström et al. 2005). Defoliations like these can also result in an altitudinal descent of the treeline, which is possibly beneficial for tundra birds (van Bogaert et al. 2011).

Some uphill shifts of the tree line, at least in parts of the Fennoscandian mountainous area, have been recorded at the same time as the regional climate has become progressively warmer and wetter. In these areas, the amount of tundra has decreased and there has potentially also been a decrease in the quantity and quality of birch forest (Kullman and Öberg 2009). Mountain habitats are also affected by plant-herbivore interactions. Several of the observed shifts in treeline altitude, either upwards or downwards, have been attributed to decreased or increased grazing of semi-domestic reindeer, live-stock and herbivore geometrids (Olofsson et al. 2009, Austrheim et al. 2010, van Bogaert et al. 2011). Clearly, the overall effects of climate change and grazing on alpine bird populations are complicated to predict, since the effects may differ between areas and between bird species. Intensive grazing with reduction of shrub thickets is found to have major negative effects not only on the bird communities of shrub habitat specialists, but also for some open-nesting species (Ims and Henden 2012).

Climate change may also have other impacts on breeding birds than through changes in the distribution and structure of vegetation zones. Mismatches between bird breeding phenology and peaks of invertebrate prey, extremely important for successfully rearing young in alpine areas, may lead to decreasing bird numbers at least in the short run (Both and Visser 2001, Knudsen et al. 2011). In western Europe, such mismatches and population declines have been shown to be greater in long-distance migrants compared to the other species. However, in northern Europe, long-distance migrants did not decline as severely as in western Europe (Both et al. 2010). Nevertheless, the potential effect of invertebrate appearance on breeding birds in the Fennoscandian mountains is unknown. In some high Arctic areas, arthropod peaks nowadays occur earlier in the summer than before (Tulp and Schekkerman 2008).

Rodent abundance in northern Fennoscandia, especially Norway lemmings Lemmus lemmus, show high annual variation usually fluctuating synchronously in three- to fiveyear cycles (Hanski et al. 1991), and these cycles may be affected by climate change (Kausrud et al. 2008). Rodents are important food for several birds of prey and skuas as well as mammal predators in the arctic, but the abundance of rodents is of importance also for other species. During high rodent densities some predators nearly exclusively base their diet on rodents, but during low rodent years, a larger proportion of predators, after years with good production and survival, need to switch to alternative prey. In tundra areas this alternative prey is typically eggs and young of bird species, but also adult individuals (Reif et al. 2001, Tornberg et al. 2011). The change in predation pressure due to rodent fluctuations has been shown to affect the breeding success of waterfowl, waders and passerines (Järvinen 1985, Sutherland 1988). However, the rodent population dynamics seem not to be responsible for the long-lasting willow ptarmigan population declines in northern Fennoscandia (Henden et al. 2011). Thus it seems quite unlikely that varying rodent abundance have affected the bird trends found during the last $11 \mathrm{yr}$ in any major way.

Our findings also showed that the two ptarmigan species experienced the most severe declines. These two species are also game species, so hunting may have affected the population declines. However, in all three countries hunting has been regulated based on the population status and bag limits and shorter hunting seasons are imposed during periods of population decline. Hunting bags are not directly comparable with the breeding census data since the bag statistics include a large proportion of young, whereas the survey data concerned adult birds in beginning of the breeding season. Nevertheless, also the hunting bag from 
Finland and Norway has more than halved since the year $2000 \quad(<$ http://tilastot.rktl.fi/database/Tilasto/4_ Metsastys/8_Metsastys/8_Metsastys_fi.asp $>$, <www.dirnat. no/skogsfugl seminar/>, accessed 29 June 2013). Therefore, it could be that the bag statistics merely mimic the status of the populations rather than hunting being the main factor driving the declines. Nonetheless, the role of hunting as a factor in the population declines should be studied in more detail (Sandercock et al. 2011).

\section{Conclusions}

Human activities, including climate change, are gradually modifying our environment. Knowledge about such effects on fauna and flora is crucial for the development of conservation strategies to minimize the loss of biodiversity and ecosystem services. Alpine and arctic habitats are expected to be particularly vulnerable to climate change (Gonzalez et al. 2010). The Fennoscandian montane bird indicator presented here gives basic information about faunistic changes in one of the most extreme climatic environments of Europe (cf. Gregory et al. 2009), covering two different habitat types: tundra and birch forest. As such, this indicator can fill an important gap among the already existing continental-wide bird indicators for farmland (Gregory et al. 2005), forest (Gregory et al. 2007), climate change (Gregory et al. 2009), and the several regional European bird indicators produced by the European Bird Census Council $(<$ www.ebcc.info $>)$. As far as we know, this may be the first large-scale indicator for alpine birds. If the new schemes that started in 2005 and 2006 will continue as planned, data will be available for a high number of sampling sites (about 400) in the coming years. This probably means that data for a few typical montane breeding bird species additional to those included here can be added to the indicator. The indicator presented here suggests that Fennoscandian montane birds have declined substantially during the last $11 \mathrm{yr}$, which is in line with the predictions based on climatic forecasting suggesting that montane species in Fennoscandia will likely show declining population sizes and reduced range sizes in the future (Huntley et al. 2007, Virkkala et al. 2008, Jiguet et al. 2013). The fact that long-distance migratory species do not stand out as particularly affected suggests that the main reasons for the decline may be found within the Fennoscandian mountain range itself.

Acknowledgements - We are most grateful to the hundreds of people who counted birds in the alpine regions of Finland, Sweden and Norway. Catherine Davey helped with map production. We thank Henriikka Simola at the Finnish Meteorological Inst., Marcus Flarup at the Swedish Meteorological and Hydrological Inst. and Ole Einar Tveito at the Norwegian Meteorological Inst. for providing weather data. The Ministry of Environment financially supports the Finnish bird monitoring. The Swedish Bird Survey is supported by grants from the Swedish Environmental Protection Agency, with additional financial and logistic support for alpine routes from the Regional County Boards (Länsstyrelsen) of Dalarna, Jämtland, Västerbotten and Norrbotten. These censuses are carried out within the framework of the Linneaus-project Centre for Animal Movement Research (CAnMove) and the strategic research environment Biodiversity and Ecosystem Services in a Changing
Climate (BECC). The Directorate for Nature Management finances the Norwegian bird monitoring as a part of the Program for Terrestrial Monitoring (TOV). Comments of Petr Voříšek improved the clarity of the manuscript. Arco van Strien helped with the statistics and Markus Öst kindly checked the English.

\section{References}

Austrheim, G., Bråthen, K. A., Ims, R. A., Mysterud, A. and Ødegaard, F. 2010. Alpine environment. - In: Kålås, J. A., Henriksen, S., Skjelseth, S. and Viken, Å. (eds), Environmental conditions and impacts for Red List species. Norwegian Biodiversity Information Centre, Norway, pp. 107-117.

Bears, H., Martin, K. and White, G. C. 2008. Breeding in highelevation habitat results in shifts to slower life-history strategy within a single species. - J. Anim. Ecol. 78: 365-375.

Benton, T. G., Vickery, J. A. and Wilson, J. B. 2003. Farmland biodiversity: is habitat heterogeneity the key? - Trends Ecol. Evol. 18: 182-188.

Böhning-Gaese, K. and Bauer, H. G. 1996. Changes in species abundance, distribution, and diversity in a central European bird community. - Conserv. Biol. 10: 175-187.

Both, C. and Visser, M. E. 2001. Adjustment to climate change is constrained by arrival date in a long-distance migrant bird. - Nature 411: 296-298.

Both, C., Van Turnhout, C. A. M., Bijlsma, R. G., Siepel, H., Van Strien, A. J. and Foppen, R. P. B. 2010. Avian population consequences of climate change are most severe for longdistance migrants in seasonal habitats. - Proc. R. Soc. B 277: 1259-1266.

Brommer, J. E. 2008. Extent of recent polewards range margin shifts in Finnish birds depends on their body mass and feeding ecology. - Ornis Fenn. 85: 109-117.

Brommer, J. E. and Møller, A. P. 2010. Range margins, climate change, and ecology. - In: Møller, A. P., Fielder, W. and Berthold, P. (eds), Birds and climate change. Oxford Univ. Press, pp. 249-274.

Byrkjedal, I. and Kålas, J. A. 2012. Censuses of breeding birds in a south Norwegian arctic-alpine habitat three decades apart show population declines in the most common species. - Ornis Norvegica 35: 43-47.

Chamberlain, D., Arlettaz, R. L., Caprio, E., Maggini, R., Pedrini, P., Rolando, A. and Zbinden, N. 2012. The altitudinal frontier in avian climate impact research. - Ibis 154: 205-209.

Chen, I. C., Hill, J. K., Shiu, H. J., Holloway, J., Benedick, S., Chey, V. K., Barlow, H. S. and Thomas, C. D. 2011. Asymmetric boundary shifts of tropical montane Lepidoptera over four decades of climate warming. - Global Ecol. Biogeogr. 20: 34-45.

Cramp, S., Simmons, K. E. L. and Perrins, C. M. 1977-1994. Handbook of the birds of the Europe, the Middle East and North America: birds of the Western Palearctic. Vol. 1-9. - Oxford Univ. Press.

Enemar, A., Sjöstrand, B., Andersson, G. and von Proschwitz, T. 2004. The 37-year dynamics of a subalpine passerine bird community, with special emphasis on the influence of environmental temperature and Epirrita autumnata cycles. - Ornis Svecica 14: 63-106.

Feeley, K. J., Silman, M. R., Bush, M. B., Farfan, W., Cabrera, K. G., Malhi, Y., Meir, P., Revilla, N. S., Quisiyupanqui, M. N. R. and Saatchi, S. 2011. Upslope migration of Andean trees. - J. Biogeogr. 38: 783-791.

Forero-Medina, G., Terborgh, J., Socolar, S. J. and Pimm, S. L. 2011. Elevational range of birds on a tropical montane gradient lag behind warming temperatures. - PLoS One 6: e28535.

Fransson, T. and Hall-Karlsson, S. 2008. Svensk ringmärkningsatlas vol. 3. - Naturhistoriska riksmuseet, Stockholm. 
Fransson, T., Österblom, H. and Hall-Karlsson, S. 2008. Svensk ringmärkningsatlas vol. 2. - Naturhistoriska riksmuseet, Stockholm.

Gilg, O., Moe, B., Hanssen, S. A., Schmidt, N. M., Sittler, B., Hansen, J., Reneerkens, J., Sabard, B., Chastel, O., Moreau, J., Phillips, R. A., Oudman, T., Biersma, E. M., Fenstad, A. A., Lang, J. and Bollache, L. 2013. Trans-equtorial migration routes, staging sites and wintering areas of a high-arctic avian predator: the long-tailed skua (Stercorarius longicaudus). - PLoS One 8: e64614.

Gonzalez, P., Neilson, R. P., Lenihan, J. M. and Drapek, R. J. 2010. Global patterns in the vulnerability of ecosystems to vegetation shifts due to climate change. - Global Ecol. Biogeogr. 19: 755-768.

Grabherr, G., Gottfried, M. and Pauli, H. 1994. Climate effects on mountain plants. - Nature 369: 448.

Gregory, R. D., van Strien, A. J., Voříšek, P., Gmelig Meyling, A. W., Noble, D. G., Foppen, R. P. B. and Gibbons, D. W. 2005. Developing indicators for European birds. - Phil. Trans. R. Soc. B 360: 269-288.

Gregory, R. D., Voř́šek, P., Van Strien, A., Gmelig Meyling, A. W., Jiguet, F., Fornasari, L., Reif, J., Chylarecki, P. and Burfield, I. J. 2007. Population trends of widespread woodland birds in Europe. - Ibis 149 (Suppl. 2): 78-97.

Gregory, R. D., Willis, S. G., Jiguet, F., Voříšek, P., Klvaňová, A., van Strien, A., Huntley, B., Collingham, Y. C., Couvet, D. and Green, R. E. 2009. An indicator of the impact of climatic change on European bird populations. - PLoS One 4: e4678.

Hanski, I. 2005. Shrinking world: ecological consequences of habitat loss. - Int. Ecol. Inst., Oldendorf.

Hanski, I., Hansson, L. and Henttonen, H. 1991. Specialist predators, generalist predators and the microtine rodent cycle. - J. Anim. Ecol. 60: 353-367.

Henden, J. A., Ims, R. A., Yoccoz, N. G. and Killengreen, S. T. 2011. Declining willow ptarmigan populations: the role of habitat structure and community dynamics. - Basic Appl. Ecol. 12: 413-422.

Hewson, C. M. and Noble, D. G. 2009. Population trends of breeding birds in British woodlands over a 32-year period: relationships with food, habitat use and migratory behaviour. - Ibis 151: 464-486.

Huntley, B., Green, R. E., Collingham, Y. C. and Willis, S. G. 2007. A climatic atlas of European breeding birds. - Durham Univ., The RSPB and Lynx Edicions, Barcelona.

Husby, M. and Kålås, J. A. 2011. Terrestriske fuglearter som indikatorer for bærekraftig utvikling i Norge. - Report no. 128, Høgskolen i Nord-Trøndelag, in Norwegian.

Ims, R. A. and Henden, J.-A. 2012. Collapse of an arctic bird community resulting from ungulate-induced loss of erect shrubs. - Biol. Conserv. 149: 2-5.

Järvinen, A. 1985. Predation causing extended low densities in microtine cycles: implications from predation on hole-nesting passerines. - Oikos 45: 157-158.

Jepsen, J. U., Hagen, S. B., Ims, R. A. and Yoccoz, N. G. 2008. Climate change and outbreak of the geometrids Operopthera brumata and Epirrita autumnata in sub-arctic birch forest: evidence of a recent outbreak range expansion. - J. Anim. Ecol. 77: 257-264.

Jepsen, J. U., Kapari, L., Hagen, S. B., Schott, T., Vindstad, O. P. L., Nilssen, A. C. and Ims, R. A. 2011. Rapid northwards expansion of a forest insect pest attributed to spring phenology matching with sub-Arctic birch. - Global Change Biol. 17: 2071-2083.

Jiguet, F., Devictor, V., Ottvall, R., van Turnhout, C., van der Jeugd, H. and Lindström Å. 2010. Bird populations trends are linearly affected by climate along species thermal ranges. - Proc. R. Soc. B 277: 3601-3608.
Jiguet, F., Barbet-Massin, M., Devictor, V., Jonzén, N. and Lindström, Å. 2013. Current population trends mirror forecasted changes in climatic suitability for Swedish breeding birds. - Bird Study 60: 60-66.

Johansson, B. 2000. Areal precipitation and temperature in the Swedish mountains. An evaluation from a hydrological perspective. - Nord. Hydrol. 31: 207-228.

Kålås, J. A. and Husby, M. 2002. Terrestrisk naturovervåking. Ekstensiv overvåking av terrestre fugl i Norge. - NINA Oppdragsmelding 740.

Kausrud, K. L., Mysterud, A., Steen, H., Vik. J. O., Østbye, E., Cazelles, B., Framstad, E., Eikeset, A. M., Mysterud, I., Solhøy, T. and Stenseth, N. C. 2008. Linking climate change to lemming cycles. - Nature 456: 93-97.

Kelly, A. E. and Goulden, M. L. 2008. Rapid shifts in plant distribution with recent climate change. - Proc. Natl Acad. Sci. USA 105: 11823-11826.

Knudsen, E., Lindén, A., Both, C., Jonzén. N., Pulido, F., Saino, N., Sutherland, W. J., Bach, L. A., Coppack, T., Ergon, T., Gienapp, P., Gill, J. E., Gordo, O., Hedenström, A., Lehikoinen, E., Marra, P. P., Møller, A. P., Nilsson, A. K., Peron, G., Ranta, E., Rubolini, D., Sparks, T. H., Spina, F., Studds, C. E., Sæther, S. A., Tryjanowski, P. and Stenseth, N. C. 2011. Challenging claims in the study of migratory birds and climate change. - Biol. Rev. 86: 928-946.

Koskimies, P. and Väisänen, R. A. 1991. Monitoring bird populations. - Zool. Mus., Finn. Mus. Nat. Hist., Helsinki.

Kullman, L. and Öberg, L. 2009. Post-Little Ice Age tree line rise and climate warming in the Swedish Scandes: a landscape ecological perspective. - J. Ecol. 97: 415-429.

Lehikoinen, A. 2013. Climate change, phenology and species detectability in monitoring scheme. - Popul. Ecol. 55: 315-323.

Lindström, A. and Agrell, J. 1999. Global change and possible effects on the migration and reproduction of arctic-breeding waders. - Ecol. Bull. 47: 145-159.

Lindström, Å., Enemar, A., Andersson, G., von Proschwitz, T. and Nyholm, N. E. I. 2005. Density-dependent reproductive output in relation to a drastically varying food supply: getting the density measure right. - Oikos 110: 155-163.

Lindström, Å., Green, M., Paulson, G., Smith, H. G. and Devictor, V. 2013. Rapid changes in bird community composition at multiple spatial scales in response to recent climate change. - Ecography doi: 10.1111/j.1600-0587. 2012.07799.x

Luckman, B. and Kavanagh, T. 2000. Impact of climate fluctuations on mountain environments in the Canadian Rockies. - Ambio 29: 371-380.

Maggini, R., Lehmann, A., Kery, M., Schmid, H., Beniston, M., Jenni, L. and Zbinden, N. 2011. Are Swiss birds tracking climate change? Detecting elevational shifts using response curve shapes. - Ecol. Model. 222: 21-32.

Martin, K. and Wiebe, K. L. 2004. Coping mechanisms of Alpine and Arctic breeding birds: extreme weather and limitations to reproductive resilience. - Integr. Comp. Biol. 44: 177-185.

Matson, P. A., Parton, W. J., Power, A. G. and Swift, M. J. 1997. Agricultural intensification and ecosystem properties. - Science 277: 504-509.

Newton, I. 1998. Population limitation in birds. - Academic Press.

Nyholm, N. E. I. 2011. Dynamics and reproduction of a nest-box breeding population of pied flycatcher Ficedula hypoleuca in a subalpine birch forest in Swedish Lapland during a period of 46 years. - Ornis Svecica 21: 133-156.

Öberg, L. and Kullman, L. 2011. Recent glacier recession - a new source of postglacial treeline and climate history in the Swedish Scandes. - Landscape Online 26: 1-38. 
Olofsson, J., Oksanen, L., Callaghan, T., Hulme, P. E., Oksanen, T. and Suominen, O. 2009. Herbivores inhibit climatedriven shrub expansion on the tundra. - Global Change Biol. 15: 2681-2693.

Ottosson, U., Ottvall, R., Elmberg, J., Green, M., Gustafsson, R., Haas, F., Holmqvist, N., Lindström, Å., Nilsson, L., Svensson, M., Svensson, S. and Tjernberg, M. 2012. The birds in Sweden - numbers and occurrence. - SOF, Halmstad, in Swedish.

Ottvall, R., Edenius, L., Elmberg, J., Engström, H., Green, M., Holmqvist, N., Lindström, A., Tjernberg, M. and Pärt, T. 2009. Population trends for Swedish breeding birds. - Ornis Svecica 19: 117-192.

Pannekoek, J. and van Strien, A. 2004. TRIM 3 manual (TRends and Indices for Monitoring data). - Statistics Netherlands, Amsterdam, Netherlands <www.ebcc.info/trim.html>.

Parmesan, C. 1996. Climate and species' range. - Nature 382: 765-766

Parmesan, C. 2006. Ecological and evolutionary responses to recent climate change. - Annu. Rev. Ecol. Evol. Syst. 37: 637-669.

Pauli, H., Gottfried, M. and Grabherr, G. 1996. Effects of climate change on mountain ecosystems: upward shifting of mountain plants. - World Resour. Rev. 8: 382-390.

Popy, S., Bordignon, L. and Prodon, R. 2010. A weak upwards elevational shift in the distributions of breeding birds in the Italian Alps. - J. Biogeogr. 37: 57-67.

Pounds, J. A., Fogden, M. P. L. and Campbell, J. H. 1999. Biological response to climate change on a tropical mountain. - Nature 398: 611-615.

Pounds, J. A., Bustamente, M. R., Coloma, L. A., Consuegra, J. A., Fogden, M. P. L., Fosterm, P. N., La Marca, E., Masters, K. L., Merino-Viteri, A., Puschendorf, R., Ron, S. R., Sánchez-Azofeifa, G. A., Still, C. J. and Young, B. E. 2006. Widespread amphibian extinctions from epidemic disease driven by global warming. - Nature 439: 161-167.

Reif, V., Tornberg, R., Jungell, S. and Korpimäki, E. 2001. Diet variation of common buzzards in Finland supports the alternative prey hypothesis. - Ecography 24: 267-274.

Sandercock, B. K., Martin, K. and Hannon, S. J. 2005. Life history strategies in extreme environments: comparative demography of arctic and alpine ptrarmigan. - Ecology 86: 2176-2186.

Sandercock, B. K., Nilsen, E. B., Brøseth, H. and Pedersen, H. C. 2011. Is hunting mortality additive or compensatory to natural mortality? Effects of experimental harvest on the survival and cause-specific mortality of willow ptarmigan. - J. Anim. Ecol. 80: 244-258.

Sanderson, F. J., Donald, P. F., Pain, D. J., Burfield, I. J. and van Bommel, F. P. J. 2006. Long-term population declines in Afro-Palearctic migrant birds. - Biol. Conserv. 131: 93-105.

Sekercioglu, C. H., Schneider, S. H., Fay, J. P. and Loarie, S. R. 2008. Climate change, elevational range shifts and bird extinctions. - Conserv. Biol. 22: 140-150.

Svensson, S. 2006. Species composition and population fluctuations of alpine bird communities during 38 years in the Scandinavian mountain range. - Ornis Svecica 16: 183-210.

Sutherland, W. J. 1988. Predation may link the cycles of lemmings and birds. - Trends Ecol. Evol. 3: 29-30.

Thomas, C. D. 2010. Climate, climate change and range boundaries. - Divers. Distrib. 16: 488-495.

Thomas, C. D. and Lennon, J. J. 1999. Birds extend their ranges northwards. - Nature 399: 213.
Thompson, D. B. A., Kålås, J. A. and Byrkjedal, I. 2012. Arcticalpine mountain birds in northern Europe: contrasts between specialists and generalists. - In: Fuller, R. J. (ed.), Birds and habitat - relationships in changing landscapes. Ecol. Rev., pp. 237-251.

Tingley, M. W. and Beissinger, S. R. 2013. Cryptic loss of montane avian richness and high community turnover over 100 years. - Ecology 94: 598-609.

Tingley, M. W., Monahan, W. B., Beissinger, S. R. and Moritz, C. 2009. Birds track their Grinnellian niche through a century of climate change. - Proc. Natl Acad. Sci. USA 106: 19637-19643.

Tingley, M. W., Koo, M. S., Mortz, C., Rush, A. C. and Beissinger, S. R. 2012. The push and pull of climate change causes heterogeneous shift in avian elevational ranges. - Global Change Biol. 18: 3279-3290

Tornberg, R., Helle, P. and Korpimäki, E. 2011. Vulnerability of black grouse hens to goshawk predation: result of food supply or predation facilitation? - Oecologia 166: 577-584.

Tulp, I. and Schekkerman, H. 2008. Has prey availability for arctic birds advanced with climate change? Hindcasting the abundance of tundra arthropods using weather and seasonal variation. - Arctic 61: 48-60.

Väisänen, R. A. 2006. Monitoring population changes of 86 land bird species breeding in Finland in 1983-2005. - Linnut-vuosikirja 2005: 83-98, in Finnish with English summary.

Väisänen, R. A., Lammi, E. and Koskimies, P. 1998. Distribution, numbers and population changes of Finnish breeding birds. - Otava, Helsinki, Finland, in Finnish with English summary.

van Bogaert, R., Haneca, K., Hoogesteger, J., Jonasson, C., De Dapper, M. and Callaghan, T. V. 2011. A century of tree line changes in sub-Arctic Sweden shows local and regional variability and only a minor influence of 20 th century climate warming. - J. Biogeogr. 38: 907-921.

Venäläinen, A., Tuomenvirta, H. and Drebs, S. 2005. A basic Finnish climate data set 1961-2000 - description and illustrations. - Finn. Meteorol. Inst., Meteorological Publications.

Virkkala, R., Heikkinen, R. K., Leikola, N. and Luoto, M. 2008. Projected large-scale range reductions of northern-boreal land bird species due to climate change. - Biol. Conserv. 141: 1343-1353.

Voříšek, P., Jiguet, F., van Strien, A., Škorpilova, J., Klvanová, A. and Gregory, R. 2010. European trends in farmland birds. - BOU Proceedings - Lowland farmland birds III. $<$ www.bou.org.uk/bouproc-net/lfb3/vorisek-etal.pdf $>$.

Wiebe, K. L. and Martin, K. 1998. Costs and benefits of nest cover for ptarmingan: changes within and between years. - Anim. Behav. 56: 1137-1144.

Wilson, J. W., Gutierrez, D., Martinez, D., Agudo, R. and Monserrat, V. J. 2005. Changes to the elevational limits and extent of species ranges associated with climate change. - Ecol. Lett. 8: 1138-1146.

Wilson, S. and Martin, K. 2010. Variable reproductive effort for two ptarmigan species in response to spring weather in a northern alpine ecosystem. - J. Avian Biol. 41: 319-326.

Wilson, S., Martin, K. and Hannon, S. J. 2007. Nest survival pattern in willow ptarmigan: influence of time, nesting stage, and female characteristics. - Condor 109: 377-388.

Zuckerberg, B., Woods, A. M. and Porter, W. F. 2009. Poleward shifts in breeding bird distributions in New York state. - Global Change Biol. 15: 1866-1883. 


\section{Appendix 1}

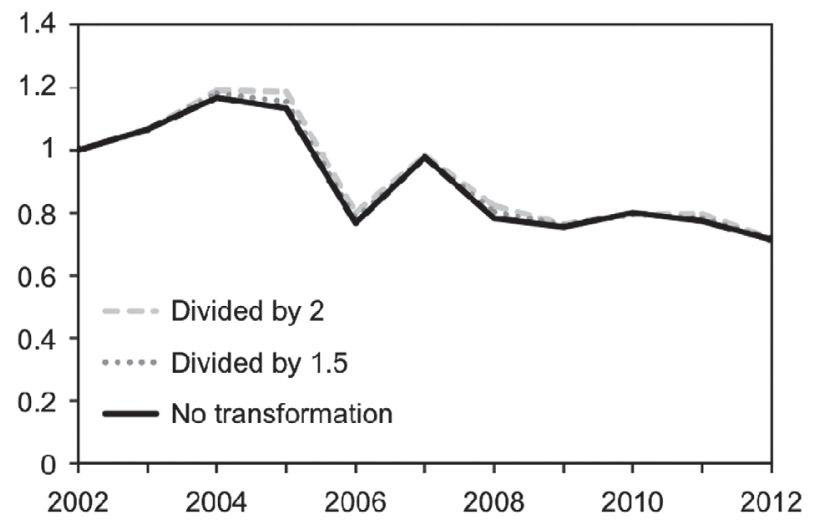

Figure A1. Geometric mean of the abundance indices of 13 montane birds (Table 2) in cases where Swedish survey numbers were divided by $1.5,2.0$ or without transformation in 2002-2012. 